\title{
Assessing the outcomes of the higher education mergers in South Africa: Implications for strategic management
}

\author{
Authors: \\ Cecil A. Arnolds ${ }^{1}$ \\ Regina N. Stofile ${ }^{2}$ \\ Riyaadh Lillah \\ Affiliations: \\ ${ }^{1}$ Graduate School of \\ Business, Nelson Mandela \\ Metropolitan University, \\ South Africa \\ ${ }^{2}$ Business Management \\ Department, Walter Sisulu \\ University, South Africa

\section{Correspondence to:} \\ Cecil Arnolds \\ Email: \\ cecil.arnolds@nmmu.ac.za \\ Postal address: \\ PO Box 77000, Port Elizabeth \\ 6031, South Africa \\ Dates: \\ Received: 14 Aug. 2012 \\ Accepted: 20 Feb. 2013 \\ Published: 22 Apr. 2013 \\ How to cite this article: \\ Arnolds, C.A., Stofile, R.N. \\ \& Lillah, R., 2013, 'Assessing \\ the outcomes of the higher \\ education mergers in South \\ Africa: Implications for \\ strategic management, Acta \\ Commercii 13(1), Art. \#175, \\ 11 pages. http://dx.doi. \\ org/10.4102/ac.v13i1.175

\section{Copyright:} \\ (C) 2013. The Authors. \\ Licensee: AOSIS \\ OpenJournals. This work \\ is licensed under the \\ Creative Commons \\ Attribution License.
}

Read online:
Objective of the study: The objective of this study is to investigate the relationship between perceived merger outcomes, employee organisational commitment and employee job performance in South African higher education institutions.

Problem investigated: High levels of negativity towards the mergers have initially been reported. The unbundling of certain mergers has been mooted. The outcomes of these mergers must therefore be evaluated.

Methodology: A total of 329 questionnaires were collected from academic and non-academic staff at three comprehensive universities. Descriptive statistics were calculated and multiple regression analysis was conducted.

Findings: The empirical results show, amongst other things, that (1) perceptions about merger goal success are significantly related to the organisational commitment and job performance intentions of employees, (2) organisational commitment levels are average and should be increased, (3) perceptions about workload fairness are significantly related to the organisational commitment of employees, and (4) employees have experienced an increased workload.

Value of study: The study emphasises the necessity of the continual management of merger goal successes, workload distributions, and administration processes and resources (especially an empowered staff) in the pursuit of stable educational environments in these institutions.

Conclusion: Managers of higher education institutions should pursue prudent strategic financial spending and continuously manage the job performance intent and organisational commitment of their staff members. If this is not done, positive perceptions of merger successes could decrease. Such a situation could perpetuate unstable conditions at already affected merged institutions and even cause stable ones to deteriorate.

\section{Introduction}

The South African Higher Education System has undergone a restructuring process of merging universities, technikons and colleges during the period 2001 to 2007. In contrast with higher education, business mergers are an everyday occurrence. Lessons could therefore be learnt from business. Managers of merging business firms often fail to consider what impact mergers have on their employees. In fact, research has shown that from $55 \%-70 \%$ of mergers fail because human resource issues are neglected (Schraeder \& Self 2003). It appears that human resource issues are also the reason why some South African higher education mergers are in trouble given the recent suggestions for the unbundling of certain merged institutions (Sidumba 2011), institutional mismanagement (Anon. 2011) and lack of access to university studies (Anon. 2012). Against this background, the present study asserts that an assessment is imperative in order to identify possible strategic management issues that might need attention. Findings from this study could assist managers of troubled merged institutions to improve the strategic management of their institutions.

\section{Literature review}

Transforming higher education through a process of mergers is not a uniquely South African phenomenon. Mergers between higher education institutions have also taken place in countries such as Australia and Canada, amongst others. The experiences of these countries in this regard are briefly reviewed.

\section{The higher education mergers in Australia}

In 1983, South Australia reduced the number of higher education institutions from 10 to three, through a series of mergers (Mildred 2002). In July 1988, the Australian federal government 
adopted a White Paper on higher education restructuring which proposed the following:

- the dismantling of the binary divide between a university and college

- strengthening the link between teaching and research

- the introduction of a new system of funding that encourages higher education institutions to diversify their funding sources

- the alignment of research with economic goals

- the promotion of focus areas in national research policy

- the placing of greater emphasis on institutional management (Dawkins 1988).

In 1996, a new funding policy framework for higher education was adopted, according to which operating grants were reduced by $5 \%$ over three years; commonwealth supplementation of academic salary increases was stopped; and the commonwealth funding of postgraduate coursework enrolment was phased out.

The institutional restructuring and new funding framework had a profoundly negative effect on higher education. These negative consequences included the neglect of basic infrastructure; the forced increases in student fees and the decrease in revenue flowing to higher education from research outputs and investments by business and industry (Gallagher 2000); the alienation of staff as a result of the cooperative style of the institutional management and the threat to the quality of teaching and research due to the decline in financial support (Wood \& Meek 2002); and the increase in the administration and teaching and research supervision workloads of academic staff (Mildred 2002).

There were, however, also positive reactions to the mergers (Wood \& Meek 2002). These included the suggestion that marketisation had made the system more responsive and relevant to industry needs, and that managers of the Australian higher education institutions had substantially increased their skills and their capacity to find new markets. This led to considerable increases in student enrolments and graduates, the creation of a multi-billion dollar overseas student market, and a substantial reduction in most institutions' financial dependence on the Commonwealth (Wood \& Meek 2002).

\section{The higher education mergers in Canada}

Post-secondary education in Canada, at both university and college levels, is the responsibility of both the provincial and territorial governments. These governments provide most of the funding for both institutions (The Council of Ministers of Education, Canada n.d.). The federal government of Canada has only an indirect influence on higher educational matters through the provision of grants, the transfer of tax points as support of research granting agencies, and student financial support. Funding therefore is provided by each respective provincial government to the post-secondary institutions through the governance processes established by each province. The educational institutions are autonomous with respect to the manner in which they fulfil statutory mandates (Shale 2002). Each respective institution, through the particular governance and budgetary processes, identifies its own priorities and the financial requirements for those priorities.

In the early 1990s, institutions in Canada came under increasing pressure from federal and provincial governments to become more accountable with regard to how they spend public funds (Association of Universities and Colleges of Canada 1991; Shale 2002). The Canadian government demanded that higher education institutions become more efficient in using their resources and more flexible in preparing students for the labour market. At the same time, both the public and government had been suggesting that much duplication existed among the universities and that some universities should be merged or closed in order to reduce costs. By merging institutions, government hoped to achieve greater efficiencies, such as educating more students without additional costs.

Some positive outcomes of the Canadian mergers have been reported. These include the increased cohesion, access and standardisation of curricula within high quality programme offerings (Barton 2005), the sharing of overhead costs, and the reduction of administrative costs (Keim 1999; Larrance 1990). Furthermore, outcomes such as the sharing of resources and expertise; greater access to programmes and services; opportunities to build skills around cooperation; increased dialogue amongst colleagues in a network of different institutions; greater diffusion of best practices; and the mobilisation for effective planning and control in higher education have also been reported (Keim 1999; Konrad \& Small 1986; Van Soeren et al. 2000).

There were also negative outcomes to the mergers reported. Baus and Ramsbottom (1999) reported that mergers are often challenged by inadequate communication and prolonged or ineffective decision-making processes. Due to the decline in funding, basic infrastructure was neglected in Australian merged universities (Gallagher 2000). Other negative outcomes of mergers include the disrespecting of institutional autonomy; lack of cohesion due to potential lack of trust and commitment; unhealthy competition amongst the members; unarticulated roles and expectations; unclear mission, structure and philosophy underpinning merged institutions; poor visibility in each member institution; and lack of participation from various groups of people (Johnson 1998; Keim 1999; Konrad \& Small 1986; Lang 2002; Van Soeren et al. 2002).

\section{The South African higher education mergers}

In March 2001, the South African Minister of Education released a National Plan for Higher Education according to which the number of public higher education institutions would be reduced from 36 to 23 through the mechanism of mergers (Ministry of Education 2001). Eleven institutions would be traditional universities, six would be universities 
of technology (formerly technikons) and there would also be six comprehensive universities (which offer both university and technikon-type programmes).

The most important reason for these mergers, according to Wyngaard and Kapp (2004), was the unification of the fragmented further and higher education systems inherited from the previous dispensation, and the need for the eradication of the profound inequalities and distortions of these education systems. Other reasons for the mergers include increasing student enrolments, especially from previously disadvantaged communities; meeting the national and global opportunities and challenges in terms of new technologies, research and training; and responding to the changing societal interests and needs as expressed in a transition from racial discrimination and oppression toward a democratic order (Mapasela \& Hay 2005).

According to Goldman and Van Tonder (2006) and Lalla (2009), most of the merged institutions are experiencing many challenges. Issues affecting all of these mergers include disparate organisational cultures and 'race' issues which manifested in diverse ways at different institutions (Gillard et al. 2012). Van Straaten Theron and Dodd (2011) claimed that mergers were stressful life-events, even in institutions with similar organisational cultures.

Gillard et al. (2012) suggest that vertical mergers between universities and technikons, which are intended to provide students with greater choice, have been negatively affected by the Higher Education National Qualifications Framework (Republic of South Africa 2011) which makes articulation difficult. This also affected the staff at these institutions who were required to upgrade their qualifications. Gillard et al. (2012) also argue that the safeguarding of vocational qualifications was undermined by the funding formula applied at these institutions and the undifferentiated requirements to increase research.

Van Straaten Theron and Dodd (2011) suggest that in some instances the employees' relationship with the organisation changed, leading to a decrease in employee commitment. Lalla (2009), for example, found that management relationships, job security, job position and promotion, communication, performance standards and collegial relationships were all negatively impacted on by the merger at a particular institution. Van Straaten Theron and Dodd (2011) warn that psychological contracts between the institutions and employees have become brittle and prone to breach, compelling management to pay closer attention to the employment relationship in order to maintain commitment and loyalty. Other matters which have not been addressed (or which have been addressed at a very slow pace) in merged institutions include salary equity and the consolidation of academic programmes (Gillard et al. 2012). Goldman (2012) also reported increased workloads at a merged institution.

Positive post-merger perceptions have also been reported (Goldman 2012). These perceptions relate to employee assertions that stronger institutions should emerge from these mergers if merger goals are achieved.

Very few positivistic studies have been done on the relationships between, on the one hand, merger goal attainment and perceptions about merger outcomes, and on the other, job performance intentions and organisational commitment of staff members of these institutions. Most of the previous studies were of a qualitative nature and intrainstitutional, for example, Fourie (1999) in anticipation of the mergers and Viljoen and Rothman (2002) and Goldman (2012) during and after the mergers respectively. The present study attempts to address this research gap by conducting a quantitative analysis of the hypothesised relationships in this study.

\section{Strategic management, job performance, organisational commitment and merger goals}

According to Thompson, Strickland and Gamble (2005), the strategic management function of an institution consists of five phases, namely (1) developing a strategic vision, (2) setting objectives, (3) creating a strategy to achieve the objectives and vision, (4) implementing and executing the strategy, and (5) monitoring developments, evaluating performance and making corrective adjustments. All the South African higher education institutions, including the merged ones, have been drawing up strategic plans which were supposed to be aligned with the vision and strategic direction of education restructuring set by the South African government. This vision and the grand strategy were not only to change the composition of staff and students, governance structures and course content, but were also to transform the organisational culture and the development and acceptance of new shared values (Fourie 1999). According to Viljoen and Rothman (2002), it was expected that the transformation of higher education in South Africa would include the revolutionary change of previous management practices; qualitative change in the experience of organisational members; and multi-dimensional change, which refers to the changes of all structures, processes and procedures and their attendant change in values, norms, attitudes, perceptions and behaviour.

The merged institutions, due to their different historical backgrounds, were particularly challenged in their ability to deliver on this vision and grand strategy. It appears that since the completion of the mergers in 2007, these merged institutions have been relatively successful in achieving the first three strategic management phases as laid down by Thompson et al. (2007). It appears, however, that some of them are still challenged in achieving phases four and five which relate to the implementation and execution of the strategy, the monitoring of developments, the evaluation of performance and the making of corrective adjustments. The fact that three merged institutions (Vaal University of Technology, Tshwane University of Technology and Walter Sisulu University) are currently (as at November 2012) placed 
under administration attests to this assertion. In addition, the unbundling of the Limpopo-Medunsa merger has been mooted.

According to Thompson et al. (2007), effective strategy execution is reliant on committed, motivated and better performing employees. It is therefore important to assess how the pursuit of merger goals relates to the job performance and organisational commitment of the staff members of the merged South African higher education institutions. In the present study, the aim is not to measure the actual job performance of employees, but is instead an expression of intent for continuous performance improvement. The researchers wanted to determine how performance intent would grow as the identification with and strategic accomplishments of the merged institutions increase. Literature suggests that performance intent is a potent predictor of actual job performance (Carkhuff 1986; Eccles et al. 2009; Shore, Newton \& Thornton 1990; Sumerlin \& Norman 1992). The study therefore investigates the relationship between the attainment or otherwise of merger goals and the performance intent of merged higher education employees.

Organisational commitment to the merged higher education institutions is critical in order to achieve the transformation strategy of the South African government. Organisational commitment increases organisational effectiveness and reduces staff turnover (Ivancevich, Konopaske \& Matteson 2008:184). Staff members who are not committed to their organisations could weaken or render their organisations ineffective through resignations. It is therefore important to assess whether a lack of organisational commitment is responsible for tensions in the troubled merged institutions. The present study follows Mowday, Porter and Steers' (1982:226) conceptualisation of organisational commitment as:

the relative strength of an individual's identification with and involvement in a particular organisation, which is characterised by a strong belief in and acceptance of the organisation's goals and values; a willingness to exert considerable effort on behalf of the organisation; and a strong desire to maintain membership in the organisation.

The present study suggests that the organisational effectiveness of the merged higher education institutions in South Africa is dependent on the positive job performance intentions and organisational commitment of the employees of these institutions. Given the challenges alluded to in the review of the South African mergers above, the study further argues that these attitudes (intentions and commitment) of the employees will be positively or negatively related to the extent to which (1) the reasons (objectives or goals) of the mergers have or have not been attained, and (2) the perceptions (positive or negative) of employees about merger outcomes are formed.

The literature (Mapasela \& Hay 2005; National Commission on Higher Education [NCHE] 1996; Wyngaard \& Kapp
2004) shows that the South African government pursued the following goals with regard to higher education mergers:

- an increased contribution to the solution of societal problems

- a better standard of higher education

- an increase in training and development of higher education staff

- increased student access

- improved administrative governance of higher education institutions

- curriculum restructuring

- improved use of financial and human resources.

A merger would therefore be successful if such an institution was successful in attaining these goals. In other words, merger goal success is defined in the present study as the perceived extent to which the above-mentioned goals have been attained in these merged institutions. The present study argues that the attainment of these goals would be positively related to organisational commitment and job performance. It is therefore hypothesised that:

H1: Perceived merger goal successes are positively related to perceived organisational commitment.

H2: Perceived merger goal successes are positively related to employee job performance (as measured by perceived performance intent).

The literature review on higher education mergers in South Africa and other countries pointed to various experiences and outcomes of these reforms. These experiences and reactions related to issues around government funding of the merged institutions (Wood \& Meek 2002); the management of the merger process (Viljoen \& Rothman 2002); cooperation amongst staff in merged institutions (Mildred 2002; Mok 2002); workloads (Goldman 2012); access to financial support from the business sector (Gallagher 2000); demand for educational services (Cloete \& Moja 2005); cost-cutting (Gallagher 2000); student debts (Gallagher 2000); the academic programme mix of merged institutions (Li 1995); and social integration of staff after mergers (Lang 2002). The present study argues that the extent to which respondents hold positive perceptions about merger outcomes will be positively related to their organisational commitment and job performance. It is therefore hypothesised that:

H3: Positive perceptions about merger outcomes are positively related to perceived organisational commitment.

H4: Positive perceptions about merger outcomes are positively related to employee job performance (as measured by perceived performance intent).

\section{The research objective}

The primary objective of the study is to contribute to the effective strategic management of the post-merger universities in South Africa by investigating the implications for managers of the perceived attainment or non-attainment of merger goals, as well as employee perceptions regarding merger outcomes. More specifically, the study investigates the relationship between the perceived attainment or nonattainment of merger goals and perceptions regarding merger 
outcomes, on the one hand, and, on the other hand, the employees' organisational commitment and job performance intent.

\section{Research methodology The sample}

Data were collected at three comprehensive universities in South Africa in 2008. Although it could be argued that the data are more than four years old, the literature review on the South African mergers above suggests that the findings (especially the challenges) that emanate from the present study are still relevant today in these institutions. This study also provides an empirical assessment of how perceptions about merger goals and outcomes are related to important employee attitudes. These data therefore still have important value.

Comprehensive universities came into being as a result of mergers between universities and technikons. The South African Department of Education (DoE) established comprehensive universities for specific purposes:

- to increase access to career-focused programmes

- to improve articulation between career-focused and general academic programmes

- to strengthen and develop applied research

- to enhance capacity to respond to the social and economic needs of the regions in which these institutions were located (Gibbon 2004).

Initially, there was huge uncertainty about how a comprehensive university would operate (Goldman 2012), making the integration of these different institutions 'fraught and complicated' (Mgqibela 2008). Due to their special focus from the DoE and their complicated beginnings, comprehensive universities were chosen as the locations for the present study.

After acquiring the permission of the Registrars of the three comprehensive universities, questionnaires were emailed to heads of divisions at these institutions requesting them to distribute the questionnaires to the staff members in their divisions. Not many questionnaires were returned. The researchers then physically distributed the questionnaires to whomever was willing to complete the questionnaires at these institutions. Some questionnaires were emailed to the respondents. This allowed the researchers to ensure as far as possible that respondents at all occupational levels completed the questionnaires. After physically and electronically (via email) distributing 200 questionnaires at University A and 500 each at Universities B and C, a total of 329 questionnaires was returned (total response rate $=14.9 \%$ ). This total comprised 82 questionnaires from University A, 120 from University B and 127 from University C. Table 1 depicts the demographic composition of the total sample.

Table 1 shows that the sample consisted of $129(39.2 \%)$ males and $200(60.8 \%)$ females, mostly academics (66\%), and was fairly evenly spread over the age groups. Most of the respondents possessed at least an honours degree and were mostly English speaking (39.2\%). Xhosa-speaking and Afrikaans-speaking respondents comprised $28.9 \%$ and $23.1 \%$ respectively of the sample. About $29 \%$ of the sample had been working for less than five years at their respective universities prior to the mergers, whilst the rest had job tenure of more than five years. About $20 \%$ of the respondents had total work experience of less than five years, whilst the rest had work experience in excess of five years.

\section{The measuring instruments}

Organisational commitment was measured using the shortened, 9-item version of the Mowday, Porter and Steers (1982) Organisational Commitment Questionnaire (OCQ). The reliability and validity of both the short and long (15item) versions have been demonstrated adequately (Brooke, Russell \& Price 1988; Matthieu \& Farr 1991).

Performance intentions have been described as a potent predictor or measure of employee job performance (Carkhuff

TABLE 1: Demographic composition of sample.

\begin{tabular}{|c|c|c|c|}
\hline Variable & Sub-catogory & $N$ & $\%$ \\
\hline \multirow[t]{2}{*}{ Gender } & Male & 129 & 39.2 \\
\hline & Female & 200 & 60.8 \\
\hline Total & - & 329 & 100.0 \\
\hline \multirow[t]{5}{*}{ Age } & $20-29$ years & 46 & 13.9 \\
\hline & $30-39$ years & 94 & 28.6 \\
\hline & $40-49$ years & 98 & 29.8 \\
\hline & $50-59$ years & 74 & 22.5 \\
\hline & $60+$ years & 17 & 5.2 \\
\hline Total & - & 329 & 100.0 \\
\hline \multirow[t]{6}{*}{ Education } & Grade 12 or equivalent & 25 & 7.6 \\
\hline & National diploma or equivalent & 43 & 13.1 \\
\hline & Bachelor's degree & 35 & 10.6 \\
\hline & Honours degree & 76 & 23.1 \\
\hline & Master's degree & 97 & 29.5 \\
\hline & Doctoral degree & 53 & 16.1 \\
\hline Total & - & 329 & 100.0 \\
\hline \multirow[t]{2}{*}{ Job category } & Academics & 217 & 66.0 \\
\hline & Non-academics & 112 & 34.0 \\
\hline Total & - & 329 & 100.0 \\
\hline \multirow[t]{5}{*}{ Language } & English & 129 & 39.2 \\
\hline & Afrikaans & 76 & 23.1 \\
\hline & Xhosa & 95 & 28.9 \\
\hline & Zulu & 12 & 3.6 \\
\hline & Other & 17 & 5.2 \\
\hline Total & - & 329 & 100.0 \\
\hline \multirow[t]{5}{*}{ Tenure } & $<5$ years & 95 & 28.9 \\
\hline & $5-9$ years & 89 & 27.1 \\
\hline & $10-14$ years & 68 & 20.7 \\
\hline & $15-19$ years & 47 & 14.2 \\
\hline & $20+$ years & 30 & 9.1 \\
\hline Total & - & 329 & 100.0 \\
\hline \multirow[t]{5}{*}{ Job experience } & $<5$ years & 65 & 19.8 \\
\hline & $5-9$ years & 88 & 26.7 \\
\hline & $10-14$ years & 58 & 17.6 \\
\hline & $15-19$ years & 55 & 16.7 \\
\hline & $20+$ years & 63 & 19.2 \\
\hline Total & - & 329 & 100.0 \\
\hline
\end{tabular}

Source: Authors' own construction 
1986; Eccles et al. 2009; Hampton, Summer \& Webber 1982; Shore et al. 1990; Sumerlin \& Norman 1992). The performance intentions scale, developed by Shore et al. (1990), was used as a surrogate measure of job performance in this study. The reported reliability coefficients, which ranged from 0.60 to 0.84 , are regarded as sufficient for use of this instrument for measurement of the performance intention construct (Shore et al. 1990).

Self-constructed instruments were used to measure merger goal success (eight items) and satisfaction with merger outcomes (13 items). The measurement items were sourced from the literature that described the experiences and reactions to the higher education mergers in South Africa and other countries (see the section on hypotheses above).

The questions in all the above-mentioned instruments were anchored on a 5-point Likert scale ranging from (1) strongly disagree to (5) strongly agree.

\section{The empirical results}

The data collected using the above-mentioned instruments were analysed by means of a computer software program (STATISTICA Version 10.0 2010). The data analyses included an assessment of the reliability and validity of the measuring instruments, as well as the multiple regression relationships amongst the variables in the hypothesised model.

\section{The reliability of the data}

The first step in the data analysis procedure was to assess the internal reliability of the data by means of Cronbach alpha coefficients. The results, reported in Table 2, show that all the instruments returned initial alpha values of more than 0.70 , which indicate good reliability according to Zikmund et al. (2010), except with regard to perceptions about merger outcomes (0.66). According to Zikmund et al. (2010), a Cronbach alpha of 0.60 represents a measure of fair reliability and all these variables were therefore retained for subsequent analyses.

\section{The validity of the data}

The second step in the data analysis procedure was to assess the discriminant validity of the data by conducting exploratory factor analyses, using the STATISTICA Version 10.0 (2010) statistical software package. Principal Component Analysis was specified as the method of factor extraction and Varimax rotation of the original factor matrix was used in all instances. Table 2 indicates the most interpretable factor structure which emerged from the factor analyses, as well as the recalculated Cronbach reliability coefficients of the variables scales as they emerged from the factor analyses. Table 2 also reveals that four variables, namely improved student access, increased higher education (HE) demand, cost-induced workload and increased university finances, did not satisfy the minimum cut-off point of 0.60 needed for fair reliability (Zikmund et al. 2010).These variables were consequently omitted from all subsequent analyses.

Table 2 also shows that merger goal success was not a single construct, but that it consisted of two constructs, namely perceptions about improved student access and perceptions about to what extent DoE goals underpinning the mergers were attained (merger goal success). In the same fashion, perceptions about merger outcomes proved to be not a single construct, but instead four variables, namely increased HE demand, cost-induced workload (the extent to which cost-saving led to increased workloads), whether university finances have increased and to what extent mergers have resulted in a fair workload distribution. The hypothesis with regard to work load fairness therefore needed to be clarified as follows:

H3a: Positive perceptions about merger outcomes (as measured by fair workload distribution) are positively related to perceived organisational commitment.

H4a: Positive perceptions about merger outcomes (as measured by fair workload distribution) are positively related to job performance (as measured by perceived performance intent).

\section{Descriptive statistics}

The data were first analysed to determine the levels of disagreement and agreement on the questionnaire items. To this end, mean scores and standard deviations were calculated. This analysis showed to what extent respondents agreed or disagreed on whether merger goals were accomplished, and the perceptions of respondents about merger outcomes.

TABLE 2: Empirical factor structure after the exploratory factor analyses.

\begin{tabular}{|c|c|c|c|c|}
\hline Latent Variable & Measuring items & Range of factor loadings & Initial alpha value & Final alpha value \\
\hline Organisational commitment & OC $1,3,5,6,7,8,9$ & $0.435-0792$ & 0.85 & 0.84 \\
\hline $\begin{array}{l}\text { Job performance } \\
\text { Intent }\end{array}$ & $\begin{array}{l}\text { PERF } 1,2,3 \\
\text { OC } 4\end{array}$ & $0.595-0.826$ & 0.75 & 0.77 \\
\hline Improved student access & OBJECT $5,7,8$ & $0.537-0.845$ & N/A & 0.54 \\
\hline Merger goal success & OBJECT 1, 2, 3, 4, 6 & $0.528-0.773$ & 0.78 & 0.76 \\
\hline Increased HE demand & OUT 6, 9 & $0.689-0.766$ & N/A & 0.29 \\
\hline Cost-induced workload & OUT 7, 11 & $0.625-0.673$ & N/A & 0.19 \\
\hline Increased university finance & OUT $1,3,5$ & $0.439-0.688$ & N/A & 0.46 \\
\hline Workload fairness & OUT $4,8,10,12$ & $0.429-0.782$ & $0.66 \dagger$ & 0.61 \\
\hline
\end{tabular}


Table 3 shows that the respondents of this study exhibited average organisational commitment (mean score $=3.13$ ). Five out of the nine questionnaire items for organisational commitment are located on the disagreement side of the 5-point scale, ranging from 2.66 to 2.99). These questionnaire items indicate that these respondents do not have a strong identification with, are not strongly committed to stay with and are not willing to exert extra effort on behalf of their organisations.

Table 4 reveals that the respondents exhibit high job performance intentions (mean score $=3.87$ ). This means that despite perceptions of an average organisational commitment, the respondents still have strong professional commitment to their jobs. This result is consistent with previous research findings (Arnolds \& Boshoff 2004; Erwee 1980).

Table 5 shows that respondents generally disagree with statements that suggest that mergers goals or objectives as envisaged by the South African government have been attained. Seven out of the eight statements, with mean scores ranging from 2.30 to 2.90 , were rated on the disagreement side of the 5-point scale, whilst the average mean score for the whole latent variable was 2.78 .

Table 6 indicates that respondents, on average, disagree that the above-mentioned merger outcomes have manifested in the South African higher education institution, as seven out of the 13 questionnaire statements were rated on the disagreement side of the 5-point scale. Table 6 also reveals that there are high levels of agreement amongst respondents regarding a stronger emphasis on cost cutting (mean score $=3.54$ ) and increased workloads (mean score $=3.50$ ) in the merged institutions. The respondents also agree that the comprehensive programme offerings enhance the status of merged institutions, that student debts have increased, that the demand for qualification offerings at their institutions has increased and that their institutions were in a better position to access financial support from business than was the case before the merger.

TABLE 3: Organisational commitment: Descriptive statistics.

\begin{tabular}{|c|c|c|}
\hline Questionnaire statement & Mean score & SD \\
\hline OC 1 I tell my friends that our merged institution is a great place to work for & 2.93 & 1.11 \\
\hline OC 2 I really care about the fate of our merged institution & 3.80 & 1.07 \\
\hline OC3 I find that my personal values and our merged institution's values are very similar & 2.97 & 1.10 \\
\hline OC4 I am willing to put in a great deal of effort beyond that normally expected in order to help our merged institution to be successful & 3.83 & 1.02 \\
\hline OC5 I am extremely glad that I work at our merged institution & 3.11 & 1.14 \\
\hline OC6 I am proud to tell others that I am employed by our merged institution & 3.21 & 1.09 \\
\hline OC7 For me our merged institution is the best of all organisations for which to work & 2.66 & 1.08 \\
\hline OC8 I would accept almost any type of job assignment in order to keep working for our merged institution & 2.70 & 1.13 \\
\hline OC9 Our merged institution inspires the very best in me in the way of job performance & 2.99 & 1.12 \\
\hline Average & 3.13 & 1.09 \\
\hline
\end{tabular}

Source: Authors' own construction

SD, standard deviation; OC, Organisational commitment.

TABLE 4: Job performance intent: Descriptive statistics.

\begin{tabular}{|c|c|c|}
\hline Questionnaire statement & Mean score & SD \\
\hline OBJECT 1 Our merger achieved what the Department of Education (DOE) intended to achieve with the higher education mergers & 2.65 & 1.02 \\
\hline $\begin{array}{l}\text { OBJECT } 2 \text { Our merged institution is in a better position to contribute to the solution of societal problems than was the case before the } \\
\text { merger }\end{array}$ & 3.03 & 1.15 \\
\hline OBJECT 4 We provide a better standard of education in the merged institution than in our previous institutions & 2.85 & 1.02 \\
\hline OBJECT 5 More students are accessing our merged institution than was the case before the merger & 3.08 & 1.03 \\
\hline OBJECT 6 The administration of my merged institution is better than it was in my previous institution & 2.30 & 1.10 \\
\hline OBJECT 8 Resources (financial and/or human) have improved to a great extent at my institution after the merger & 2.53 & 1.10 \\
\hline Average & 2.78 & 1.08 \\
\hline
\end{tabular}

$4.28 \quad 0.90$


TABLE 6: Perceptions about merger outcomes: Descriptive statistics.

\begin{tabular}{|c|c|c|}
\hline Questionnaire statement & Mean score & SD \\
\hline OUT 1 Government funding of our merged institution has increased after the merger & 2.81 & 1.00 \\
\hline OUT 2 Our management has successfully managed the merger process & 2.71 & 1.10 \\
\hline OUT 3 There has been an improvement in cooperation amongst staff after our merger & 2.81 & 1.06 \\
\hline OUT 4 The workload allocation to staff in our merged institution is fair & 2.59 & 1.23 \\
\hline OUT 5 Our merged institution is in a better position to access financial support from big business than prior to the merger & 3.13 & 1.01 \\
\hline OUT 6 Many more educational services are demanded from merged institutions & 3.64 & 0.88 \\
\hline $\begin{array}{l}\text { OUT } 7 \text { There is a stronger emphasis on cutting costs in our merged institution than was the case in our previous unmerged institutions } \\
\text { (R) }\end{array}$ & $3.54(2.47)$ & 1.10 \\
\hline OUT 8 In my merged institution, we all had our say in the determination of our workload formula & 2.57 & 1.15 \\
\hline OUT 9 Our merger has led to a bigger student debt (R) & $3.19(2.81)$ & 0.95 \\
\hline OUT 10 The comprehensive programme mix improves the academic status of my merged institution & 3.15 & 1.02 \\
\hline OUT 11 My workload has increased after the merger (R) & $3.50(2.51)$ & 1.20 \\
\hline OUT 12 Social integration of staff has taken place in my merged institution & 2.81 & 1.09 \\
\hline OUT 13 The merger has succeeded in reducing the operational costs of the new institution & 2.65 & 1.03 \\
\hline Average & 2.82 & 1.06 \\
\hline
\end{tabular}

Source: Authors' own construction

$\mathrm{R}$, item was reverse-scored.

SD, standard deviation; OUT, merger outcomes.

It must be noted that items OUT9 (increased student debt) and OUT11 (increased workloads) are generally not viewed as positive outcomes of mergers (Mildred 2002; Wood \& Meek 2002). Similarly, an emphasis on cost-cutting (OUT7), to the extent that it leads to a lack of financial support for the mergers (Wood \& Meek 2002), is also not regarded as a positive merger outcome. In the context of positive merger outcomes, as measured in Table 6 above, these three outcome items were therefore reverse-scored in the calculation of the average perceptions of respondents. This means that, on the question of whether or not these three outcomes were positive ones, the respondents would disagree.

\section{Multiple regression analysis}

The next analysis, namely multiple regression analysis, involved the relationships between perceived attained merger objectives and perceptions about merger outcomes, on the one hand, and organisational commitment and job performance, on the other. The results are summarised in Tables 7 and 8.

The empirical results reveal that perceived merger goal success is significantly positively related to organisational commitment $(0.64, p<0.001)$ and job performance intent $(0.40, p<0.001)$. Both hypotheses $\mathrm{H} 1$ and $\mathrm{H} 2$ were therefore supported. This means that the more staff members feel that the mergers were successful in accomplishing the objectives they set out to achieve, the stronger their organisational commitment and job performance intent would be.

The empirical results show that perceived workload distribution fairness is significantly positively correlated with organisational commitment $(0.19, p<0.001)$, but not with employee job performance intent. Hypothesis H3 was therefore supported, whilst hypothesis $\mathrm{H} 4$ was not. This result indicates that employees' perceptions with regard to whether the merger has resulted in a fair workload dispensation are related to their organisational commitment but not to their
TABLE 7: The relationship between merger goal success, perceptions about merger outcomes and organisational commitment

\begin{tabular}{lcccc}
\hline $\begin{array}{l}\text { Dependent variable: } \\
\text { Organisational } \\
\text { commitment }\end{array}$ & B & Std.Err. - of B & $\boldsymbol{t}(\mathbf{3 2 6})$ & $\boldsymbol{p}$-value \\
\hline Intercept & - & - & 5.28852 & 0.000000 \\
Object & 0.641807 & 0.043328 & 14.81258 & $0.000000 *$ \\
Outcome & 0.191911 & 0.043328 & 4.42921 & $0.000013^{*}$ \\
\hline
\end{tabular}

Source: Authors' own construction

Adjusted $R^{2}, 0.58791076 ; F(2,326), 234.97, p<0.0000$

$*$, indicates a significant level of $p<0.001$

TABLE 8: The relationship between merger goal success, perceptions about merger outcomes and job performance intent.

\begin{tabular}{lcccc}
\hline $\begin{array}{l}\text { Dependent variable: Job } \\
\text { performance intent }\end{array}$ & B & Std.Err. - of B & $\boldsymbol{t}(\mathbf{3 2 6})$ & $\boldsymbol{p}$-value \\
\hline Intercept & - & - & 17.98173 & 0.000000 \\
\hline Object & 0.397593 & 0.060650 & 6.55547 & $0.000000^{*}$ \\
\hline Outcome & 0.074132 & 0.060650 & 1.22228 & 0.222486 \\
\hline
\end{tabular}

Source: Authors' own construction

Adjusted $R^{2}, 0.58791076 ; F(2,326), 234.97, p<0.0000$

$*$, indicates a significant level of $p<0.001$

job performance intent. This result is understandable, as employees would harbour negative feelings toward their institutions if these institutions were seen to be unfair as far as their workload dispensation is concerned. The result also provides further support for the assertion that university employees possess strong professional commitment, as negative feelings about bigger workloads would not cause employees to reduce their job performance deliberately.

Tables 7 and 8 reveal that the perceived success of merger goal attainment and the perception about fair workload distribution together account for almost 59\% (adjusted $\left.R^{2}=0.587\right)$ of the variance in organisational commitment and about 19\% (adjusted $R^{2}=0.192$ ) of the variance in job performance intent. This means that these two latent variables are important correlates of increased organisational commitment and job performance intent and therefore warrant higher education managers' attention.

The above-mentioned results are illustrated in Figure 1. 


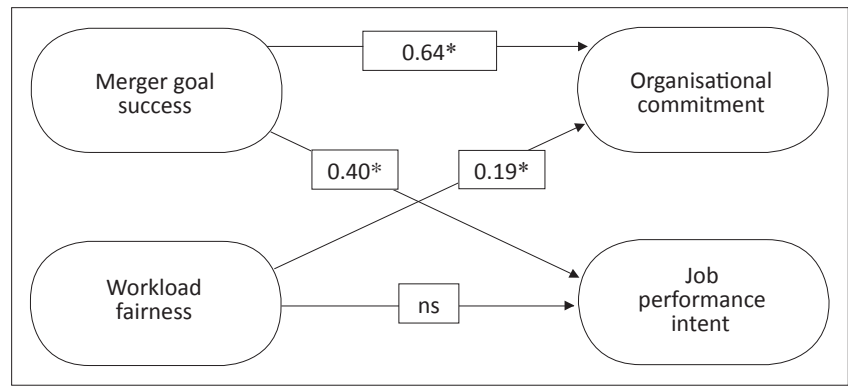

Source: Authors' own construction

*, indicates a significant level of $p<0.001 ; \mathrm{ns}$, not significant.

FIGURE 1: The relationship between merger goal success, perceptions about merger outcomes, organisational commitment and job performance intent.

\section{Discussion of results and managerial implications}

It must be noted from the outset that the empirical results of the present study are not claiming to be applicable to all merged South African higher education institutions in general or comprehensive universities in particular, due to the unrepresentative nature of the sample. The study was conducted in only three of the six comprehensive universities which have on average (except the University of South Africa's 4000) a staff complement of 2300 members. The sample size in the present study was 329 . The study can also not claim to represent the 12 merged higher education institutions in South Africa. The study did, however, produce important findings that could serve as lessons for other merged (including comprehensive) universities.

The empirical results show that the strongest factor related to organisational commitment in the context of the sampled higher education mergers is perceptions about merger success $(0.64, p<0.001)$. Employees' organisational commitment to their merged institutions can therefore be increased if they perceive the mergers as accomplishing what they set out to achieve. The empirical results (Table 4) also revealed that organisational commitment levels are average in the sample of merged institutions and should be increased. At a strategic management level, it is therefore imperative for the managers of these merged institutions to manage employees' perceptions about mergers, more specifically, highlighting and celebrating merger successes. Merger successes that need to be highlighted include whether the new merged institution is in a better position to contribute to the solution of societal problems than was the case premerger; whether a better standard of education has been achieved in the merged institution than in the previously separate constituents; whether more services are demanded from merged institutions than before; and whether the mergers have achieved an increase in training and staff development.

The empirical results show that the employees' organisational commitment is significantly positively related to their perceptions about workload fairness $(0.19, p<0.001)$ in the sampled institutions. It therefore appears that the employees' commitment to their merged institutions is strongly related to perceptions about how fairly they are treated in terms of workload. The descriptive statistics (Table 6) have shown that employees experience an increased workload (OUT11). They are also of the view that their workloads are not distributed fairly (OUT4) and that they do not have a say in their workload allocation (OUT8). Issues concerning workload have the potential to reduce the organisational commitment of employees and therefore deserve the attention of the managers of the sampled institutions. It is recommended that the executive managers of these institutions conduct workload studies aimed at ensuring fair workload distribution amongst staff members. It is also important to facilitate the participation of staff members in achieving a fair workload dispensation.

Perceptions about whether the DoE-envisaged merger goals have been successfully attained in the sampled institutions were strongly related $(0.40, p<0.001)$ to the job performance intentions of their staff members. This means that the management of these institutions should continuously highlight and innovatively build on the successes of the merged institution. To this end, managers should increase their investment in staff development programmes that would empower staff members to take part creatively in new institutional projects. For example, multi-disciplinary research projects could be supported, both in terms of finances and training, in order to stimulate and maintain collaboration between staff members who came from the different institutions which constituted the merger. It is then also important to celebrate the successes that emerge from these collaborations, as this would reinforce positive perceptions about the merger. In addition, the same activities proposed earlier in order to improve organisational commitment in this discussion section should be pursued so as to improve job performance intent.

The empirical results revealed three further important areas of concern, namely that the administration and resourcing (human and financial) of the sampled merged institutions (OBJECT 6 and 8 in Table 5 ) are perceived not to have necessarily improved due to the merger and that the operational costs have not decreased as was envisaged. This means that managers of the sampled institutions should, to the extent that these operational costs are justified on administration and human and financial resources, pursue prudent strategic financial spending. If this is not done, positive perceptions of merger successes could decrease, which could in turn result in decreased levels of employee job performance intent and organisational commitment. Such a situation could perpetuate unstable conditions already prevalent in one of the sampled institutions and could cause even stable ones to deteriorate.

On a positive note, the empirical results confirmed the professional commitment of employees in higher education institutions. Despite their perceptions that the envisaged merger goals have to a large extent not materialised, coupled with their perceptions that most outcomes of their mergers have not been positive, the respondents of the sampled 
institutions still exhibit strong positive job performance intentions (see Table 4). Higher education managers should therefore reinforce these positive performance intentions with employee empowerment programmes that would enable employees to initiate more successes. Productive staff members should be rewarded with workload reductions to allow them the space in which they could create and innovate.

\section{Conclusion}

The study highlighted the importance of managing the job performance intent and organisational commitment of employees in merged higher education institutions in South Africa. It also emphasised the necessity of the continual strategic management of merger goal successes and workload distribution in the sampled institutions. Finally, the empirical results pointed to the importance of the judicious management of administration processes and resources (especially an empowered staff) in the pursuit of stable educational environments in the merged higher education institutions investigated in this study.

\section{Acknowledgments Competing interests}

The authors declare that they have no financial or personal relationship(s) which may have inappropriately influenced them in writing this paper.

\section{Authors' contributions}

C.A.A. (Nelson Mandela Metropolitan University) was the project leader and wrote the whole manuscript, and R.L. (Nelson Mandela Metropolitan University) made contributions to the literature review. The manuscript was based on the master's study of R.N.S., which was completed at the Nelson Mandela Metropolitan University.

\section{References}

Anon., 2011, 'Walter Sisulu University under administration', New24, viewed 02 November 2011, from http://www.news24.com/SouthAfrica/News/WalterSisulu-University-under-administration-20111102

Anon., 2012, 'Crisis at tertiary institutions - ANCYL', News24, viewed 12 January 2012 from http://www.news24.com/SouthAfrica/Politics/Crisis-at-tertiary-institutionsANCYL-20120112

Arnolds, C.A. \& Boshoff, C., 2004, 'The management of the early stages of restructuring in a tertiary-education institution: An organisational commitment perspective', South African Journal of Business Management 35(2), 1-13.

Association of Universities and Colleges of Canada, 1991, Commission of Inquiry on Canadian University Education: Survey of the Perception of Universities among Provincial Government Officials (Research Report 5), Association of Universities and Colleges of Canada, Ottawa.

Barton, L., 2005, 'On the cutting edge: Rethinking governance in inter-institutional cooperation arrangements in higher education', College Quarterly 8(1), 1-16.

Baus, F. \& Ramsbottom, C., 1999, 'Starting and sustaining a consortium', New Directions for Higher Education 27(2), 3-18. http://dx.doi.org/10.1002/he.10601

Brooke, P.P., Russell, D.W. \& Price, J.L., 1988, 'Discriminant validity of measures of job satisfaction, job involvement and organisational commitment', Journal of Applied Psychology 73(2), 139-145. http://dx.doi.org/10.1037/0021-9010.73.2.139

Carkhuff, R.R., 1986, Human processing and human productivity, Human Resource Development Press, Amherst, MA.

Cloete, N. \& Moja, T., 2005, 'Transformation tension in higher education: Equity, efficiency and development', Social Research 72(3), 693-722.

Dawkins, J., 1988, Higher Education: a policy statement, Australian Government Printing Services, Canberra.
Eccles, M.P., Hrisos, S., Francis, J.J., Steen, N., Bosch, M. \& Johnston, M., 2009, 'Can the collective intentions of individual professionals within healthcare teams predict the team's performance: developing methods and theory', teams predict the team's performance: developing methods and theory',
Implementation Science 4, 24, viewed 05 December 2012, from http://www. implementation Science 4, 24, view/ $/ 4 / 1 / 24$

Erwee, R., 1980, 'Professional and organisational commitment of university research professors', South African Journal of Business Management 11, 21-26.

Fourie, M., 1999, 'Institutional transformation at South African universities: Implications for academic staff', Higher Education 38(3), 275-290. http://dx.doi. org/10.1023/A:1003768229291

Gallagher, M., 2000, 'The emergence of entrepreneurial public universities in Australia', paper presented at the IMHE General Conference of the OECD, Paris, September 2000.

Gibbon, T., 2004, Creating comprehensive universities in South Africa: a concept document, Department of Education, Pretoria.

Gillard, E., Saunders, S., Terblanche, J. \& Sukel, M., 2012, 'A review of four case studies in restructuring the South African Higher Education System', viewed 18 July 2012, from http://ahero.uwc.ac.za/index.php?module=cshe\&action=viewtitle\&id=cs he_842

Goldman, G.A., 2012, 'Exploring academics' experience of a merger in Higher Education: the reflective experience of mergers (REM) framework', African Journal of Business Management 6(14), 4862-4879.

Goldman, G.A. \& Van Tonder, C., 2006, 'The University of Johannesburg merger academics' experience of the pre-merger phase', Acta Comercii 6, 147-161.

Hampton, D.R., Summer, C.E. \& Webber, R.A., 1982, Organisational Behaviour and Practice of Management, Scott, Foresman and Company, Glenview, IL.

Ivancevich, J.M., Konopaske, R. \& Matteson, M.T., 2008, Organizational Behavior and Management, McGraw-Hill/Irvin, Boston.

Johnson, D., 1998, 'The limits of cooperation', in D. Neal (ed.), Consortia and Interinstitutional cooperation, pp. 193-199, Collier MacMillan Publishers, New York.

Keim, M., 1999, 'Educational consortia - A longitudinal study', College \& University 74(3), 30-36.

Konrad, A. \& Small, J., 1986, 'Consortia in postsecondary education', The Canadian Journal of Higher Education 16(1), 73-84.

Lalla, V., 2009, 'The impact of the merger on the employees of Tshwane University of Technology', unpublished Masters dissertation, Faculty of Humanities, University of Pretoria.

Lang, D.W., 2002, 'A lexicon of inter-institutional cooperation', Higher Education 44 153-183. http://dx.doi.org/10.1023/A:1015573429956

Larrance, A., 1990, 'What small colleges can do together', New Directions for Higher Education 27(2), 109-113.

Li, Z.C., 1995, 'Problems in institutional links should be noted', China Education Daily, November, $9,3$.

Mapasela, M. \& Hay, H.R., 2005, 'Through the magnifying glass: A descriptive theoretical analysis of possible impact of the South African higher education policies on academic staff and their job satisfaction', Higher Education 50, 111128. http://dx.doi.org/10.1007/s10734-004-6358-9

Matthieu, J.E. \& Farr, J.L., 1991, 'Further evidence for the discriminant validity of measures of organisational commitment, job involvement and job satisfaction' Journal of Applied Psychology 76(1), 127-133. http://dx.doi.org/10.1037/0021 9010.76.1.127

Mgqibela, L., 2008, 'Comprehensive university reality "fraught and complicated", University World News, Issue 1, 29 January 2008.

Mildred, G., 2002, 'Launching the United National System: What happened in South Australia', Higher Education 44(1), 29-51. http://dx.doi. org/10.1023/A:1015556910392

Ministry of Education, 2001, 'National Plan for Higher Education', viewed 28 May 2008, from http://sun025.sun.ac.za/portal/page/portal/Administrative Divisions/INB/ Home/Documentation/Documentation National/National\%20Plan\%20for\%20 Higher\%20Education\%20in\%20South\%20Africa.pdf

Mok, K.H., 2002, 'From nationalisation to marketisation: Changing governance in Taiwan's higher education systems', Governance 15(2), 137-160. http://dx.doi. org/10.1111/1468-0491.00183

Mowday, R.T., Porter, L.W. \& Steers, R.M., 1982, Employee-organisational Linkages: The Psychology of Commitment, Absenteeism and Turnover, Academic Press, New York.

National Commission on Higher Education (NCHE), 1996, NCHE Report: A framework for transformation, Department of Education, Pretoria.

Republic of South Africa, 2011, (Department of Higher Education and Training), The General and Further Education and Training Qualifications Framework 558(34883), 1-111.

Schraeder, M. \& Self, D.R., 2003, 'Enhancing the success of mergers and acquisitions: An organisational culture perspective', Management Decision 41(5), 511-522. http://dx.doi.org/10.1108/00251740310479359

Shale, D., 2002, 'The hybridisation of higher education in Canada', The Internationa Review of Research in Open and Distance Learning 2(2), 1492-3831.

Shore, L.M., Newton, L.A. \& Thornton, G.C., 1990, 'Job and organisational attitudes in relation to employee behavioural intentions', Journal of Organisational Behaviou 11, 57-67. http://dx.doi.org/10.1002/job.4030110108 
Sidumba, L., 2011, 'Don't close under-fire Medunsa - report', News24, viewed 24 July 2011, from http://www.news24.com/SouthAfrica/Politics/The-universitynobody-wants-to-touch-20110723-2

STATISTICA Version 10.0, 2010, StatSoft Incorporated, available from www.statsoft. com

Sumerlin, J.R. \& Norman, R.L., 1992, 'Self-actualisation and homeless men: A knowngroup examination of Maslow's hierarchy of needs', Journal of Social Behaviour and Personality $7(3), 469-481$

The Council of Ministers of Education, Canada. n.d., 'Education in Canada: an overview', viewed 04 February 2013, from http://www.cmec.ca/299/Educationin-Canada-An-Overview/index.htmI\#02.

Thompson, A.A., Strickland, A.J. \& Gamble, J.E., 2005, Crafting and executing strategy: The quest for competitive advantage, McGraw-Hill/Irwin, Boston.

Van Soeren, M., Andrusyszyn, M., Laschinger, H.S., Goldenberg, D. \& DiCenso, A., 2000, 'Consortium approach for nurse practitioner education', Journal of Advanced Nursing 32(4), 825-833.
Van Straaten Theron, A. \& Dodd, N.M., 2011, 'Organisational commitment in a postmerger situation', South African Journal of Economic and Management Sciences 14(3), 333-345.

Viljoen, J.P. \& Rothman, S., 2002, 'Transformation in a tertiary education institution: A case study', Management Dynamics 11(2), 2-10.

Wood, F. \& Meek, L., 2002, 'Over-reviewed and underfunded? The evolving policy context of Australian higher education research and development', Journal of Higher Education Policy and Management 24(1), 7-25. http://dx.doi. of Higher Education Policy and

Wyngaard, A. \& Kapp, C., 2004, 'Rethinking and reimagining mergers in further and higher education: A human perspective', South African Journal of Higher Education 18(1), 185-201. http://dx.doi.org/10.4314/sajhe.v18i1.25437

Zikmund, W.G., Babin, B.J., Carr, J.C. \& Griffin, M., 2010, Business Research Methods, Cengage Learning, Canada. 